\title{
PENGARUH KEBIASAAN SARAPAN TERHADAP KONSENTRASI BELAJAR MAHASISWA STIKES PERSADA NABIRE PROVINSI PAPUA
}

\section{THE EFFECT OF BREAKFAST HABITS ON STUDENT LEARNING CONCENTRATION AT STIKES PERSADA NABIRE PAPUA PROVINCE}

\author{
Nur Al-faida \\ Program Studi Gizi Sekolah Tinggi Ilmu Kesehatan Persada Nabire \\ Jl. Yapis, Karang Mulia, Nabire, 98811, Papua, Indonesia \\ email: alfaidanur@gmail.com
}

\begin{abstract}
Breakfast is an important thing for everyone to start their activities. Breakfast provides energy and nutrients, especially carbohydrates that the body uses to increase blood sugar levels. Normal blood sugar levels will make a better person's concentratio, so that it has a positive impact on productivity. The purpose of this study was to determine the effect of breakfast habits towards student learning concentration at STIKes Persada Nabire Papua Province. This research used cross sectional study design which was conducted at STIKes Persada Nabire starting from October to November 2020. The population is all students in semester 1 and 3 as many as 55 people, but we used simple random sampling method with a total sample of 36 people became respondents. The variables of studies included characteristic of students, breakfast habits and learning concentration. The research instrument involed in this study such as a list of questions in the form of questionnaires, meters and scales. The data obtained were processed by SPPS and analyzed using the chi-square test. The results of this study showed that most of the students did not have breakfast habits (55.6\%). There is a significant relationship between breakfast habits and learning concentration ( $p$ value < 0.02). Meanwhile, students who have the habit of having breakfast in the morning do not have good concentration in studying. Furthermore, students are expected to have regular breakfast habits with the quantity and quality of a good food that can meet their daily energy intake needs.
\end{abstract}

Keyword: Breakfast Habits, Study Concentration, Students

\begin{abstract}
Abstrak
Sarapan merupakan hal penting bagi setiap orang untuk mengawali aktifitasnya. Sarapan pagi mampu memenuhi kebutuhan energi dan zat gizi terutama karbohidrat yang digunakan tubuh untuk meningkatkan kadar gula darah. Kadar gula darah normal berfungsi untuk mengoptimalkan tingkat konsentrasi seseorang menjadi lebih baik sehinga berdampak positif terhadap produktifitas. Tujuan dari penelitian ini adalah untuk mengetahui pengaruh kebiasaan sarapan terhadap konsentrasi belajar mahasiswa di STIKes Persada Nabire Provinsi Papua. Penelitian ini memiliki desain cross sectional study yang dilakukan di STIKes Persada Nabire dimulai pada bulan Oktober sampai dengan November 2020. Populasi yaitu seluruh mahasiswa semester 1 dan 3 sebanyak 55 orang dengan metode simple random sampling dengan jumlah sampel sebanyak 36 orang. Variabel yang diteliti adalah karakteristik mahasiswa, kebiasaan sarapan dengan konsentrasi belajar. Instrumen penelitian yang digunakan adalah daftar pertanyaan berupa kuesioner, meteran dan timbangan badan. Adapun data yang diperoleh dianalisis menggunakan uji chi-square. Hasil penelitian ini menunjukkan sebagian besar mahasiswa tidak memiliki kebiasaan sarapan $(55,6 \%)$. Terdapat hubungan yang signifikan antara kebiasan sarapan terhadap konsentrasi belajar ( $p$ value $<0,02$ ). Mahasiswa yang memiliki kebiasaan sarapan di pagi hari belum memiliki konsentrasi belajar yang baik sehingga diharapkan
\end{abstract}


mahasiswa STIKes Persada Nabire memiliki kebiasaan sarapan yang teratur dengan kuantitas dan kualitas makanan yang dapat memenuhi kebutuhan asupan energi harian.

Kata kunci: Kebiasaan sarapan, Konsentrasi belajar, Mahasiswa

\section{PENDAHULUAN}

Sarapan pagi merupakan hal yang sangat penting bagi setiap orang untuk memulai segala aktifitasnya sepanjang hari. Sarapan pagi adalah kegiatan makan dan minum yang dilakukan sejak bangun pagi sampai pukul 9.00 yang bertujuan untuk memenuhi $15-30 \%$ asupan zat gizi harian (Hardiansyah, 2012). Namun, tidak setiap orang di Indonesia menerapkan kebiasaan untuk mengawali hari dengan sarapan. Berdasarkan data Riset Kesehatan Dasar (2013), sebanyak 16,9-50\% anak usia sekolah dan remaja, serta $31,2 \%$ orang dewasa di Indonesia tidak biasa melakukan sarapan pagi.

Beberapa penelitian bahkan menunjukkan bahwa kualitas sarapan yang dimiliki oleh sebagian peserta didik di Indonesia belum memenuhi kebutuhan asupan harian. Hasil penelitian Putra (2018) menujukkan bahwa sebanyak 56\% mahasiswa Universitas Ngudi Waluyo dari semester 1 -7 memiliki frekuensi sarapan jarang. Penelitian lain juga menunjukkan hasil yang hampir sama yaitu sebanyak 77,8\% mahasiswa fakultas Kedokteran Universitas Riau jarang melakukan sarapan karena berbagai macam alasan salah satunya terburu - buru dikarenakan kuliah pagi. Mahasiswa yang melakukan sarapan juga memiliki kualitas sarapan yang tidak memenuhi standar kecukupan gizi asupan harian (Kurniyanti, 2017).

Manfaat sarapan terpenting untuk tubuh yaitu dapat membantu mempertahankan kadar glukosa dalam darah. Mengingat jarak antara makan malam dengan pagi sangat panjang yaitu kurang lebih 10 jam, kadar glukosa darah yang merupakan sumber energi dalam tubuh menurun di pagi hari. Oleh karena itu, meninggalkan sarapan pagi akan menyebabkan tubuh kekurangan glukosa sehingga berakibat pada semua aktivitas tubuh seperti kemampuan berfikir dan konsentrasi dapat terganggu (Saragi, 2015).

Sarapan pagi mampu memenuhi kebutuhan energi dan zat gizi terutama karbohidrat yang digunakan tubuh untuk meningkatkan kadar gula darah. Kadar gula darah normal berfungsi untuk mengoptimalkan tingkat konsentrasi seseorang menjadi lebih baik sehinga berdampak positif terhadap produktifitas. Peserta didik yang tidak sarapan, kurang dapat mengerjakan tugas di kelas yang memerlukan konsentrasi, sehingga mereka mendapat nilai hasil ujian yang rendah, menurunnya daya ingat bahkan sering absen di kelas karena sakit (Muchthar dkk, 2011).

Konsentrasi yang menurun akibat tidak melakukan sarapan, secara jangka panjang dapat menurunkan hasil prestasi belajar. Hal ini dikarenakan, hampir seluruh aktifitas belajar membutuhkan konsentrasi tinggi untuk meningkatkan kemampuan kognitif. Kemampuan kognitif yang baik berdampak pada terserapnya seluruh ilmu dalam kegiatan belajar mengajar tersebut. Oleh karenanya sarapan sangat berkorelasi dengan konsentrasi yang tinggi sehingga berperan dalam peningkatan prestasi belajar (Setiawan dan Haridito, 2015).

Mahasiswa sarjana merupakan fase transisi antara remaja dan dewasa yang memiliki aktivitas yang cukup padat terutama untuk kegiatan akademik yang membutuhkan konsentrasi tinggi (Lestari, 2019). Aktivitas yang cukup padat tersebut harus ditunjang oleh pemenuhan energi dan zat gizi dalam sehari secara optimal (Lestari, 2019). Sarapan yang dikonsumsi peserta didik setidaknya menyuplai kebutuhan gizi sebesar 15\%-20\% dari kebutuhan gizi harian per individu (Hardinsyah dan Aries, 2012).

Sarapan yang baik adalah makanan harus banyak mengandung karbohidrat karena akan merangsang glukosa dan mikro nutrient dalam otak yang dapat menghasilkan energi, selain itu berfungsi memacu otak agar membantu memusatkan pikiran atau konsentrasi untuk belajar dan memudahkan penyerapan pelajaran (Winata, 2015).

Meskipun sudah mengetahui manfaat pentingnya sarapan, namun tidak semua mahasiswa sempat melakukan sarapan di pagi hari. Sebuah penelitian menunjukkan mahasiswa memilih untuk tidak melakukan sarapan dengan berbagai alasan seperti terlambat bangun pagi, tidak sempat karena aktifitas kuliah jam 7 pagi, tidak terbiasa 
sarapan, merasa sakit perut jika sarapan, malas, sibuk kerja (labor), dan tidak sesuai selera (Purnawinadi dan Lotulung, 2020).

Berdasarkan beberapa alasan yang sudah dikemukakan diatas, peneliti bertujuan untuk melakukan studi mengenai "pengaruh kebiasaan sarapan terhadap konsentrasi belajar mahasiswa STIKes Persada Nabire, Provinsi Papua".

\section{METODE PENELITIAN}

Penelitian ini merupakan penelitian kuantitatif, dengan desain penelitian cross sectional. Desain cross sectional yaitu jenis penelitian yang menekankan pada waktu pengukuran atau observasi data pada satu waktu yang dilakukan untuk mejawab pertanyaan penelitian. Pendekatan ini digunakan untuk melihat pengaruh antara variabel satu dengan variabel lainnya (Sastroasmoro, 2011).

Penelitian ini dilakukan pada Bulan Oktober sampai dengan November tahun 2020 di STIKes Persada Nabire. Populasi dalam penelitian ini adalah seluruh mahasiswa STIKes Persada Nabire sebanyak 55 orang. Sampel penelitian sebanyak 36 responden yang diambil dengan menggunakan teknik simple random sampling. Simple random sampling adalah pengambilan anggota sampel dari populasi yang dilakukan secara acak tanpa memperhatikan strata yang ada dalam populasi (Sugiyono, 2017).

Pengambilan sampel dilakukan dengan cara menulis nama pada kertas, dibentuk lotre, diletakkan dalam wadah, kemudian dikocok dan dijatuhkan. Instrumen penelitian yang digunakan adalah daftar pertanyaan berupa kuesioner, meteran, dan timbangan badan. Hasil dari penelitian selanjutnya di analisis dengan menggunakan analisis univariat dan bivariat (chi-square).

\section{HASIL DAN PEMBAHASAN}

\section{Karakteristik responden}

Berdasarkan hasil penelitian kebiasaan sarapan terhadap konsentrasi belajar mahasiswa STIKes Persada Nabire Provinsi Papua, maka dapat ditampilkan karakteristik responden pada Tabel 1.

Data pada Tabel 1 menunjukkan karakteristik responden yang terdiri dari jenis kelamin, umur, suku, berat badan dan tinggi badan. Berdasarkan jenis kelamin, sebanyak
$22,2 \%$ berjenis kelamin laki - laki sedangkan sisanya $77,8 \%$ berjenis kelamin perempuan. Responden yang berumur 15-25 tahun berjumlah $88,9 \%$ dan sisanya $11,1 \%$ berumur 26-35 tahun. Respoden yang termasuk ke dalam Suku Mee sebanyak 58,3\%, Suku Dani 19,4\%, dan Suku lainnya 22,2\%.

Responden dengan berat badan $40-50 \mathrm{~kg}$ sebanyak 22,2\%, berat badan 51-60 kg sebanyak $55,6 \%$, dan berat badan $61-70 \mathrm{~kg}$ sebanyak $22,2 \%$. Hampir seluruh responden memiliki tinggi badan antara 140-160 cm $(83,3 \%)$, sedangkan responden yang memiliki tinggi badan $161-180 \mathrm{~cm}$ adalah $16,7 \%$.

Tabel 1. Karakteristik Responden Mahasiswa STIKes Persada Nabire Provinsi Papua

\begin{tabular}{lrr}
\hline Variabel & $\begin{array}{c}\text { Frekuensi } \\
(\mathbf{n})\end{array}$ & $\begin{array}{c}\text { Persentase } \\
(\%)\end{array}$ \\
\hline Jenis Kelamin & & \\
Laki-laki & 8 & 22,2 \\
Perempuan & 28 & 77,8 \\
Umur & & \\
15-25 Tahun & 32 & 88.9 \\
26-35 Tahun & 4 & 11,1 \\
Suku & & \\
Mee & 21 & 58,3 \\
Dani & 7 & 19,4 \\
Lainnya & 8 & 22,2 \\
Berat Badan & & \\
40-50 kg & 8 & 22,2 \\
$51-60 \mathrm{~kg}$ & 20 & 55,7 \\
61-70 kg & 8 & 22,2 \\
Tinggi Badan & & \\
$140-160 \mathrm{~cm}$ & 30 & 83,3 \\
$161-180 \mathrm{~cm}$ & 6 & 16,7 \\
\hline
\end{tabular}

Kebiasaan sarapan dan konsentrasi belajar Sebanyak 44,4\% mahasiswa memiliki kebiasaan sarapan di pagi hari. Pada variabel konsentrasi belajar, jumlah mahasiswa yang dinyatakan memiliki konsentrasi belajar yang baik sejumlah $47,2 \%$, sisanya $52,8 \%$ memiliki konsentrasi belajar yang kurang.

Tabel 2. Kebiasaan Sarapan dan Konsentrasi Belajar Mahasiswa STIKes Persada Nabire Papua

\begin{tabular}{lrr}
\hline Variabel & $\begin{array}{c}\text { Frekuensi } \\
(\mathbf{n})\end{array}$ & $\begin{array}{c}\text { Persentase } \\
(\%)\end{array}$ \\
\hline Kebiasaan Sarapan & & \\
$\quad$ Tidak Pernah & 20 & 55,6 \\
$\quad$ Sering & 16 & 44,4 \\
Konsentrasi Belajar & & \\
$\quad$ Baik & 17 & 47,2 \\
Kurang & 19 & 52,8 \\
\hline
\end{tabular}




\section{Pengaruh Kebiasaan Sarapan terhadap Konsentrasi Belajar Mahasiswa STIKes Persada Nabire Provinsi Papua.}

Data pada Tabel 3 menunjukkan hubungan antara kebiasan makan dengan konsentrasi belajar mahasiswa STIKes Persada Nabire. Berdasarkan hasil penelitian terhadap 36 mahasiswa, menunjukkan bahwa terdapat hubungan antara kebiasaan makan dengan tingkat konsentrasi belajar $(p$-value $<0,05)$.

Tabel 3. Hubungan Antara Kebiasaan Sarapan dengan Konsentrasi Belajar Mahasiswa STIKes Persada Nabire Papua

\begin{tabular}{|c|c|c|c|c|}
\hline \multirow{2}{*}{$\begin{array}{c}\text { Kebiasaan } \\
\text { sarapan }\end{array}$} & \multicolumn{2}{|c|}{$\begin{array}{c}\text { Konsentrasi } \\
\text { Belajar }\end{array}$} & \multirow{2}{*}{$\begin{array}{c}\text { Jumlah } \\
(\%)\end{array}$} & \multirow{2}{*}{ p-value } \\
\hline & $\begin{array}{c}\text { Baik } \\
(\%)\end{array}$ & $\begin{array}{c}\text { Kurang } \\
(\%)\end{array}$ & & \\
\hline $\begin{array}{l}\text { Tidak } \\
\text { pernah }\end{array}$ & $13(36,1)$ & $7(19,4)$ & $20(55,6)$ & 0,02 \\
\hline Sering & $4(11,1)$ & $12(33,3)$ & $16(44,4)$ & \\
\hline
\end{tabular}

Hasil penelitian yang dilakukan di STIKes Persada Nabire Provinsi Papua menunjukkan bahwa mahasiswa yang tidak terbiasa melakukan sarapan justru memiliki konsentrasi yang lebih baik $(36,1 \%)$ dibandingkan dengan konsentrasi yang kurang $(19,4 \%)$. Pola yang hampir sama juga ditemukan pada kelompok mahasiswa yang memiliki kebiasan sering sarapan di pagi hari. Mahasiswa yang memiliki kebiasaan sarapan di pagi hari justru memiliki konsentrasi yang kurang $(33,3 \%)$ dibandingkan dengan yang memiliki konsentrasi yang baik $(11,1 \%)$

Penelitian ini tidak sejalan dengan penelitian Nurul Hidayah (2019) yang menyimpulkan bahwa semakin baik sarapan kebiasaan siswa, konsentrasi belajar juga semakin baik. Begitu juga, tidak sejalan dengan penelitian lain yang dilakukan oleh Ferawati dan Sri Sundari (2017) tentang kebiasaan sarapan pagi dengan konsentrasi belajar yang menunjukkan terdapat hubungan kebiasaan pagi dengan konsentrasi belajar siswa-siswi kelas VI SD Muhammadiyah Karang Tengah Imogiri Bantul Yogyakarta.

Hasil ini berkaitan dengan mahasiswa yang mengikuti penelitian ini tidak ditanyakan jumlah kuantitas dan kualitas sarapan yang sudah dilakukan. Mereka hanya mendapat pertanyaan bahwa apakah terbiasa sarapan atau tidak. Dengan demikian, kualitas dan kuantitas dari sarapan yang mereka lakukan tidak dapat tergambarkan dengan jelas.
Pola sarapan ini sangat menentukan asupan glukosa yang dapat diberikan kepada otak sehingga dapat diolah menjadi sumber energi untuk beraktifitas termasuk di dalamnya untuk berkonsentrasi dan berfikir saat kegiatan belajar. Apabila asupan sarapan dari mahasiswa tidak mendapat glukosa yang cukup, maka fungsi otak atau memori dapat terganggu. Pakar gizi, Khomsan (2004) menyebutkan menu sarapan hendaknya memiliki komposisi gizi cukup dan seimbang. Menu sarapan lebih diutamakan kandungan gula sebaiknya memenuhi $58 \%$ energi (terdiri dari $2 / 3$ gula kompleks dan $1 / 3$ gula cepat terserap) sedangkan lemak 30\% (2/3 lemak tidak jenuh dari nabati dan $1 / 3$ asal hewani, ikan dan ternak) dari kebutuhan energi harian.

Sarapan pagi yang baik harus banyak mengandung karbohidrat karena akan merangsang glukosa dan mikro nutrient dalam otak yang dapat menghasilkan energi, selain itu dapat berlangsung memacu otak agar membantu memusatkan pikiran untuk belajar dan memudahkan penyerapan pelajaran (Winata, 2015).

Proporsi pemenuhan zat-zat gizi dalam sehari berasal dari: sarapan memberikan 14\%, makan siang memberikan $44 \%$, makan selingan memberikan $14 \%$ (masing-masing $7 \%$ untuk selingan pagi dan sore) dan makan malam memberikan $28 \%$. Jika tidak ada makanan selingan di pagi hari, proporsi sarapan adalah $20 \%$ dari kebutuhan zat gizi dalam sehari. Ini juga menjadi kelemahan dalam penelitian ini, dimana tidak diukurnya asupan cemilan yang dilakukan oleh mahasiswa STIKes Persada di pagi hari. Cemilan juga memegang peranan penting untuk menambah asupan glukosa dalam darah meskipun lebih dianjurkan untuk dipenuhi dalam bentuk sarapan pagi yang utuh terdiri dari karbohidrat, protein, lemak, serta serat. Asupan serat yang tinggi juga merupakan salah satu cara untuk menahan rasa lapar dan memberikan efek kenyang lebih lama karena memiliki indeks glikemiks yang tinggi (Almatsier, 2010).

\section{KESIMPULAN DAN SARAN}

\section{Kesimpulan}

Sebagian besar mahasiswa tidak memiliki kebiasaan sarapan. Sebagian besar mahasiswa mahasiswa juga memiliki konsentrasi belajar yang kurang. Hal ini dapat 
berdampak pada hasil belajar yang tidak maksimal selama melaksanakan perkuliah. Hasil uji menunjukkan bahwa terdapat hubungan yang signifikan antara kebiasaan makan dengan konsentrasi belajar mahasiswa.

\section{Saran}

Mengingat pentingnya sarapan pagi, mahasiswa diharapkan untuk lebih rajin melakukan sarapan agar dapat meningkatkan konsentrasi belajar maupun kaitan dengan kesehatan. Bagi peneliti selanjutnya diharapkan dapat melakukan penelitian mengenai faktorfaktor yang mempengaruh kebiasaan sarapan, dan juga kualitas dan kuantitas sarapan terhadap konsentrasi belajar pada mahasiswa. Sebaiknya kalori yang dikonsumsi saat sarapan adalah 300 kalori. Jenis bahan makanan yang dapat digunakan sebagai menu alternatif sarapan antara lain ialah nasi uduk, telur, telur, tempe, timun, lontong sayur labu, telur bulat, tahu, nasi tim ayam, telur lengkap dengan kuah sayuran, bubur manado, potongan ikan, bubur ayam, telur rebus dan kacang. Berbagai menu sarapan sehat tersebut dapat dilengkapi dengan buah buahan seperti pisang, papaya, semangka dan apel.

\section{DAFTAR RUJUKAN}

1] Almatsier S. (2010). Prinsip dasar ilmu gizi. Jakarta: Gramedia Pustaka Utama

2] Ferawati dan Sri Sundari. (2017). Hubungan Kebiasaan Sarapan Pagi dengan Konsentrasi Belajar Siswa-Siwi SD Muhammadiyah Karang Tengah Imogir BantulYogyakarta. $\quad$ 8(No.2):12-18. https://jurnal.akbiduk.ac.id/assests/doc/180 7300914377.SARAPAN\%20\%20\%DENG AN\%20KONSENTRASI\%20BELAJAR.p df. Diakses tanggal 14 Desember 2020.

3] Hardiansyah. (2012). Jenis Pangan Sarapan dan Perannya dalam Asupan Gizi Harian Anak Usia 6-12 Tahun di Indonesia. Jurnal Gizi dan Pangan 7(94).

4] Khomsan A. (2004). Peranan pangan dan gizi untuk kualitas hidup. Jakarta: PT Gramedia Widiasarana Indonesia.

5] Kurniyanti I, Christianto E, Ismawati. (2017). Gambaran Sarapan dan Status Gizi Pada Mahasiswa Fakultas Kedokteran Universitas Riau Angkatan 2017. Jurnal Ilmu Kedokteran. 12(2):10-17. Doi: $\underline{10.26891 / J I K . v 12 i 2.2018 .108-112}$
6] Lestari AD. (2019). Hubungan sarapan pagi dengan konsentrasi belajar di SMK Bumantara Muntilan Jurusan Farmasi. Yogyakarta: UNY. Diakses dari http://repository2.unw.ac.id/446/

7] Muchtar, Julia, Gamayanti. (2011). Sarapan dan Jajan Berhubungan Dengan Konsentrasi belajar pada Remaja. Jurnal Gizi Klinik Indonesia.

8] Nurul Hidayah. (2019). Hubungan Kebiasaan Sarapan dengan Konsentrasi Belajar pada Siswa SMK Kesehatan Nur Medika Surabaya. http://repository.wima.ac.id/19171/\#: :text =Yang\%20berarti\%20bahwa\%20semakin \%20baik.meningkatkan\%20konsentrasi\%2 Obelajar\%20padaq\%20siswa. Diakses tanggal 14 Desember 2020.

9] Purnawinandi IG dan Lotulung CV. (2020). Kebiasaan Sarapan dan Konsentrasi Belajar Mahasiswa. Nutrix Jurnal 4(No. 1): 31-38. Diakses dari https://www.researchgate.net/publication/3 41024337_kebiasaan_sarapan_dan_konsen trasi_belajar_mahasiswa

10] Putra A, Syafira DN, Maulyda S, Afandi A, Wahyuni S. (2018). Kebiasaan Sarapan pada Mahasiswa Aktif. Higeia.2 (4):12-18. Doi:https://doi.org/10.15294/higeia.v2i4.2 6803

11] Riset Kesehatan Dasar RI. (2013). Badan Penelitian dan Pengembangan Kesehatan RI tahun 2013. http://www.depkes.go.id/resources/downlo ad/general/Hasil\%20Riskesdas\%202013.p df . Diakses tanggal 15 Oktober 2020.

12] Saragi. (2015). Hubungan sarapan pagi dengan aspek biologis anak usia sekolah. Program studi ilmu keperawatan Universitas Riau 2 (No 2).

13] Sastroasmoro $S$ dan Ismael S. (2011). Dasar-dasar Metodologi Penelitian Klinis. Binarupa Aksar. Jakarta.

14] Setiawan M.N dan Haridito I. (2015). Hubungan status gizi dengan tingkat kosentrasi belajar siswa. E-Journal UnesaJurnal Kesehatan Olahraga 3(No. 1): 1220.

15] Sugiyono. (2017). Metode Penelitian Kuantitatif, Kualitatif, dan $R \& D$. Bandung: Alfabeta, CV 
86 Ikesma: Jurnal Ilmu Kesehatan Masyarakat, Vol. 17, No. 2 September 2021, 81-86

16] Winata HY. (2015). Hubungan Perilaku Sarapan dengan Konsentrasi Belajar Mahasiswa Tahun Ketiga Program Studi Ilmu Keperawatan Universitas Muhammadiyah Yogyakarta. Yogyakarta: UMY. Diakses dari http://thesis.umy.ac.id/datapublik/t53268. 